\title{
The composition and diversity of arbuscular mycorrhizal fungi in karst soils and roots collected from mulberry of different ages
}

\author{
Dan Xing ${ }^{1,2}$ (-) Zhenhong Wang ${ }^{3 *}$ Jiujun Xiao $^{4}$ Shiyu Han $^{2}$ Chaobin Luo ${ }^{2}$ \\ Aimin Zhang ${ }^{2}$ Lala Song ${ }^{2}$ Xiubin Gao $^{5}$
}

${ }^{1}$ College of Forestry, Guizhou University, Guiyang, China.

${ }^{2}$ Research Institute of Sericulture, Guizhou Academy of Agricultural Science, Guiyang, China.

${ }^{3}$ School of Environmental Science and Engineering, Chang'an University, Xi'an, China. E-mail: w_zhenhong@126.com. "Corresponding author. ${ }^{4}$ Research Institute of Mountain Resources, Guizhou Province, Guiyang, China.

${ }^{5}$ Research Institute of Tea, Guizhou Academy of Agricultural Science, Guiyang, China.

\begin{abstract}
Arbuscular mycorrhizal fungi (AMF) have been attracted more scientific attentions due to its critical role in enhancement of drought tolerance of plants for growth and vegetation restoration in karst fragile ecosystem. However, scientists know little about the AMF composition and diversity occurring in root systems of mulberry (Morus sp.), and in karst habitats which return land use from mulberry forestry, as well as the effects of soil environment change on the diversity of the AMF communities. To understand: (1) the AMF community composition and diversity at different stage of returning cropland to forest; and (2) the effects of soil environment change on the diversity of the AMF communities, soil and mulberry root samples were collected from Bijie and Libo sites, China, which experienced one and ten years, respectively, after returning croplands to forest. With the high throughput 454-sequencing technology, $8 \mathrm{known}$ genera including 83 virtual species were distinguished and the genera Glomus, Paraglomus, Archaeospora and Diversispora were found to be dominant in soil and root sample. Compared to the samples in Libo, the genera Glomus, Paraglomus, Acaulospora and Claroideoglomus in root samples at Bijie site had a relatively abundance of species indicating that the returning cropland to forest is benefit to the AMF diversity and abundance, which was attribute to the variation of soil physiochemical properties. This conclusion is of great significance for guiding the return of farmland to forests. Key words: mycorrhizal biotechnology, Morus sp., rocky desertification, root, soil properties.
\end{abstract}

Composição e diversidade de fungos micorrízicos arbusculares em solos cársticos e raízes de amoreira de diferentes idades

RESUMO: Fungos micorrízicos arbusculares (FMA) tem atraído atenções de cientistas devido ao seu papel fundamental no crescimento e na restauração da vegetação de ecossistemas frágeis. No entanto, o conhecimento da composição e da diversidade da FMA em habitats cársticos e que retornem da agricultura para a silvicultura é limitado. Para entender: (1) a composição da Comunidade FMA e diversidade em fase diferente de retornar cultivo para a floresta; e (2) os efeitos da mudança do ambiente do solo sobre a diversidade das comunidades FMA, mostras de solo e de raiz de amoreira (Morus sp.) foram coletadas em Bijie e Libo, China, após um e dez anos de retorno ao cultivo dessa espécie, respectivamente, em sequência ao cultivo agrícola. Utilizando análise molecular e sequenciamento genético, constatou-se oito gêneros conhecidos e a distincão de oitenta e três espécies de FMA. Os gêneros Glomus, Paraglomus, Archaeospora e Diversispora foram dominantes, em solo e raízes. Em comparação as amostras de Libo, os gêneros Glomus, Paraglomus, Acaulospora e Claroideoglomus foram relativamente abundante nas raizes coletadas em Bijie, indicando que o retorno de uma área agrícola para o cultivo de amoreira é benéfico para a diversidade dos FMA, o que é atribuido as propriedades fisico-químicas do solo. Essa conclusão é de grande importância para avaliar os efeitos do tipo de uso agrícola na microbiologia do solo.

Palavra-chave: biotecnologia microbiana, Morus sp., desertificação rochosa, raiz, propriedades do solo.

\section{INTRODUCTION}

Due to ecological fragility and the impacts of farming for food supplies on cropland, much land in southern karst region of China has been transformed into a rocky landscape almost devoid of soil and vegetation, i.e.; rocky desertification (WANG et al., 2004). Rocky desertification which is a unique type of desert characterized by intense soil erosion and low land productivity has become an important ecological and environmental problem. It restricts the sustainable development 
in karst areas (WANG et al., 2004; LI et al., 2009). The southwest karst region, centered in Guizhou Province, China, is the largest continuous karst region in the world (GUO et al., 2013). The expansion of rocky desertification leads to extremely unstable ecosystems, and the poverty of people living in the region. For mitigating the rocky desertification, the returning cropland to forest, an important engineering, was vigorously promoted by the government in the southwest karst region (GUO et al., 2013). In the plant-soil system of the engineering, soil water is a key factor for forest recovery. Although annual precipitation was abundant in the region, the scarcity of soil water was still the primary obstacle in the returning cropland to forest due to the uneven distribution of precipitation in the spatial and temporal (GUO et al., 2011). Thus, a drought-tolerant plant, mulberry (Morus sp.) is widely applied in the returning cropland to forest. In the one hand, mulberry which has strong resistance to drought with the symbiosis between arbuscular mycorrhizal fungi (AMF) and mulberry roots is easy to survive. In the other hand, mulberry plantation could produce some economic benefit to the farmer, which is easy to promote in the southwest karst region, China (QIN et al., 2012). Allied to this factor, the use of biotechnological tools, such as AMF, may favor reforestation of degraded karstic ecosystems.

Recently, symbiosis between AMF and plant has been attracted more attention in the scientific community because AMF could improve the ability of host plant to uptake water and nutrients (VAN DER HEIJDEN, 2004). AMF also accelerates the formation of soil aggregates, which reduces the water and nutrient leaching losses (VAN DER HEIJDEN, 2006). It is attributed to the hyphae produced by AMF which bound with soil particles (SIMARD \& DURALL, 2004; WAGG et al., 2011; WALDER \& WIEMKEN, 2012). AMF greatly enhances the stability of soil structure and directly absorbs soil water and nutrients from rhizosphere soil. There have been reports that the inoculation of AMF improved the mulberry transplant survival rate based on the increase of its water use efficiency and photosynthetic capacity in karst rocky desertification land (CHEN et al., 2014; PIAO et al., 2016). Also, the inoculation of AMF was found to improve dry matter accumulation in mulberry leaves, biomass production and alkaline-tolerance (RAJAGOPAL et al., 1989; KATIYAR et al., 1989; CHEN et al., 2014; KASHYAP et al., 2004; KUNJUPILLAI, 2009; SHI et al., 2016). Some studies further showed that the link between plant roots and rhizosphere soil called the hyphae network is a critical factor to affect the water use efficiency and nutrient supply, which has a close relationship with the diversity of AMF (KOIDE, 2000; MAHERALI \& KLIRONOMOS, 2007; VAN DER HEIJDEN et al., 2008; HOEKSEMA et al., 2010; VAN DER HEIJDEN et al., 2016). For example, in especial environments, some plant species have distinctive AMF communities, and display certain preferences for some AMF (BEVER, 2002; VANDENKOORNHUYSE et al., 2003). Therefore, identifying the AMF composition and further screening high efficient AMF species will benefits to the water use efficiency and nutrient supply, and ultimately improve the restoration of kart desertification land (HASELWANDTER \& BOWEN, 2002; LEUNG et al., 2007). Especially in the administration of rock desertification, understanding the AMF community composition and diversity at the different stages after returning cropland to forest, and selecting dominant species has practical significances. Once the AMF community composition and diversity were clarified and the dominant species were screened in the different stages of returning farmland to forest, the forestry sector could inoculate the dominant species of AMF to mulberry, which means that many ecological problems such as drought, lack of fertilizer can be effectively alleviated in the rocky desertification areas.

Previous studies have found that the maintenance of the stability in plant community and re-establishing vegetation was mainly dependent on the composition and diversity of AMF in the fragile and degraded ecosystems of southwest China (ZHANG et al., 2004; ZHAO \& ZHAO, 2007; LI et al., 2010). Furthermore, the composition and diversity of AMF were temporally and spatially changeable, and the drivers of the changes were correlated with land use and environmental factors such as soil properties and climate (KLEIN et al., 2004; WANG et al., 2014; XIANG et al., 2014). However, the information on the composition and diversity of AMF autogenously or artificially inoculated in mulberry roots is still limited. According to previously mentioned, in this study we hypothesized that spatio-temporal dynamics of AMF communities were associated with times of returning cropland to forest and soil environment in the mulberry forest. Therefore, Bijie site where mulberry plantation has been conducted for ten years and Libo site where mulberry plantation has been performed for one year were chosen to study the AMF community composition and diversity. 
We aimed to understand: (1) the AMF community composition and diversity at different stage of returning cropland to forest; and (2) the effects of soil environment change on the diversity of the AMF communities.

\section{MATERIALS AND METHODS}

\section{Study sites}

Samples of soils and mulberry roots were collected from two mulberry fields at Bijie and Libo sites, which were selected based on sites grown with mulberry trees in different temperature and rainfall conditions, and the different time courses that land use at the two sites were returned from cropland to forest in the karst region (Figure 1). Bijie site is in Bijie city in Guizhou province $\left(105^{\circ} 33^{\prime} 49^{\prime \prime} \mathrm{E}, 27^{\circ} 41^{\prime} 12^{\prime \prime} \mathrm{N}\right)$, which is subject to the subtropical monsoon climate, with the average annual temperature of $13.4^{\circ} \mathrm{C}$ and the mean annual precipitation of $864 \mathrm{~mm}$. The cropland at the site changed into mulberry fields ten years ago. Libo site is located within Libo country in Guizhou province $\left(108^{\circ} 03^{\prime} 06^{\prime \prime} \mathrm{E}, 25^{\circ} 15^{\prime} 12^{\prime \prime} \mathrm{N}\right)$, which is also subject to the subtropical monsoon climate, with the annual average temperature of about $19.7^{\circ} \mathrm{C}$ and the annual rainfall of $1263 \mathrm{~mm}$. The cropland at the site changed into mulberry fields only one year ago. Soil properties are listed in table 1.

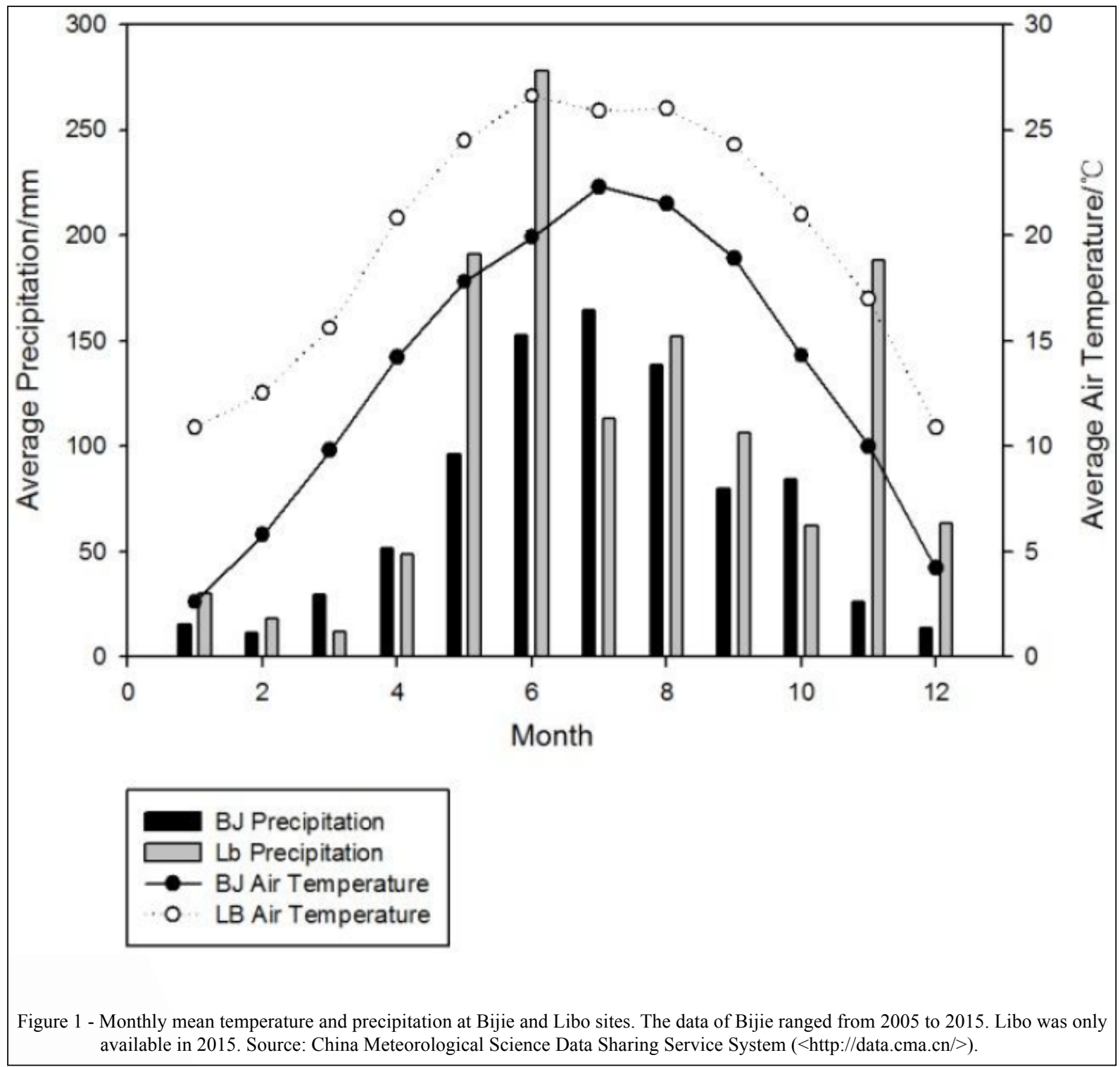

Ciência Rural, v.48, n.10, 2018. 
Table 1 - Physical and chemical properties of soil samples collected from Bijie and Libo sites.

\begin{tabular}{lcccccccc}
\hline Site & $\mathrm{pH}$ & $\mathrm{OM}\left(\mathrm{g} \cdot \mathrm{kg}^{-1}\right)$ & $\mathrm{TCa}\left(\mathrm{g} \cdot \mathrm{kg}^{-1}\right)$ & $\mathrm{TN}\left(\mathrm{g} \cdot \mathrm{kg}^{-1}\right)$ & $\mathrm{TP}\left(\mathrm{g} \cdot \mathrm{kg}^{-1}\right)$ & $\mathrm{AP}\left(\mathrm{mg} \cdot \mathrm{kg}^{-1}\right)$ & $\mathrm{TK}\left(\mathrm{g} \cdot \mathrm{kg}^{-1}\right)$ & $\mathrm{AK}\left(\mathrm{mg}^{-1} \mathrm{~kg}^{-1}\right)$ \\
\hline Bijie & $6.88 \pm 0.51$ & $20.37 \pm 7.39$ & $6.22 \pm 3.24$ & $2.33 \pm 0.85^{*}$ & $0.32 \pm 0.19^{* * *}$ & $6.40 \pm 4.27$ & $10.40 \pm 0.99^{* * *}$ & $33.83 \pm 16.34^{* * *}$ \\
Libo & $6.79 \pm 0.35$ & $22.65 \pm 5.79$ & $6.04 \pm 5.44$ & $2.08 \pm 1.19$ & $0.48 \pm 0.33$ & $6.18 \pm 4.84$ & $4.92 \pm 0.69$ & $18.08 \pm 9.23$ \\
\hline
\end{tabular}

OM: organic matter; TCa: total Ca; TN: total nitrogen; TP: total phosphorous; AP: available phosphorous; TK: total potassium; AK: available potassium. All data was presented with means $\pm \mathrm{SD}(\mathrm{N}=15) .{ }^{*}$ significance level: $P<0.05 ;{ }^{* * *}$ significance level: $P<0.001$.

\section{Sampling and samples preparation}

For observation of the seasonal variation of AMF, the samples of mulberry roots and soils were collected on Jan. 27 and 29, Apr. 16 and 21, Jul. 16 and 20, and Oct. 16 and 22 in 2015. The different sampling months represented winter, spring, summer and autumn, respectively. At each site, using one-to-one correspondence method, the samples of mulberry roots and soils were collected at depths of $0-10,10-20,20-30$, and $30-40 \mathrm{~cm}$. Then, the samples of mulberry roots were picked out with tweezers from soil samples. Meanwhile, the samples of mulberry roots and soils were separately placed into the polyethylene bags in a portable deepfreeze. After returning to laboratory, the root samples were carefully rinsed with tap-water and distilled water to remove the soils on the surface of the root samples. Then all root samples were cut off one-centimeter length and were stored at $-80^{\circ} \mathrm{C}$ for the subsequent molecular analysis of AMF. The soil samples were divided into two parts. One part was stored at $-80^{\circ} \mathrm{C}$ for the subsequent molecular analysis of AMF. Another part was air-dried and passed through $2 \mathrm{~mm}$ sieves for a test of soil chemical property.

\section{Soil analysis}

Soil $\mathrm{pH}$ was determined with an acidity measurer at dilution ratios of $1 \mathrm{~g}$ of soil to $2.5 \mathrm{~mL}$ of distilled water. Soil organic matter (OM) was determined by the $\mathrm{K}_{2} \mathrm{Cr}_{2} \mathrm{O}_{7}$ oxidation method (WALKLEY, 1947). Total Ca (T-Ca) was extracted with $0.5 \mathrm{M} \mathrm{HNO}_{3}$ and analyzed by using atomic absorption spectrophotometry (MARSHALL, 1967; MORGAN \& MORRIS, 1982). Total nitrogen (TN) was extracted with concentrated $\mathrm{H}_{2} \mathrm{SO}_{4}$ and catalyst tellurium and analyzed by using Kjeldahl method (LIAO, 1982). Total phosphorus (TP) was digested with the sequential addition of concentrated $\mathrm{H}_{2} \mathrm{SO}_{4}$ $\mathrm{H}_{2} \mathrm{O}_{2}$-HF and analyzed by using Mo-Sb colorimetric method (SEKIYA, 1970; BOWMAN, 1988). Total potassium (TK) was extracted with the sequential addition of concentrated $\mathrm{HNO}_{3}-\mathrm{HCl}$ and analyzed by using flame photometer (NATHAN GAMMON, 1951). Soil available phosphorus (AP) was extracted with $0.5 \mathrm{M} \mathrm{NaHCO}_{3}$ and measured using the Mo-Sb anti-spectrophotometry method (OLSEN et al., 1954). Available potassium (AK) was extracted with $1.0 \mathrm{~mol}$ $\mathrm{L}^{-1} \mathrm{NH}_{4} \mathrm{Ac}$ and measured with flame photometer.

\section{Molecular analyses of arbuscular mycorrhizal fungi DNA extraction}

Total DNA in the root samples was isolated from $50 \mathrm{mg}$ of root samples using the MoBioPowerPlant ${ }^{\circledR}$ Pro DNA Isolation Kits (Mo Bio Laboratories, Inc.; Carlsbad, CA, USA) according to instruction manual. The total DNA in the soil sample was extracted from $500 \mathrm{mg}$ of soil samples using the Fast DNATM Spin Kit for Soil (MP Biomedicals, LLC, Santa Ana, CA, USA) following the manufacturer's instruction. The purity and concentration of extracted DNA from all root and soil samples were measured using NanoDrop 2000 (Thermo Sientific, Wilmington, DE, USA), and DNA integrity was examined by gel electrophoresis (1\% agarose).

\section{Nested PCR amplification \\ Nested-PCR was carried out using} TransStart Fastpfu DNA Polymerase (TransGen AP221-02), and three primer pairs were selected for AMF community analyses (Table 2 ). The $20 \mu \mathrm{L}$ of double-distilled water containing $4 \mu \mathrm{L} 5 \times$ Fast Pfu Buffer, $2 \mu \mathrm{L} 2.5 \mathrm{mM}$ dNTPs, $0.8 \mu \mathrm{L} 5 \mu \mathrm{M}$ Forward Primer, $0.8 \mu \mathrm{L} 5 \mu \mathrm{M}$ Reverse Primer, $0.4 \mu \mathrm{L}$ Fast Pfu Polymerase and 10ng Template DNA was added into the PCR reaction system. The first PCR reaction was performed using the primers AML1-AML2 (LEE et al., 2008) as follows: initial denaturation at $94^{\circ} \mathrm{C}$ for $5 \mathrm{~min} ; 32$ cycles at $94^{\circ} \mathrm{C}$ for $30 \mathrm{~s}, 58^{\circ} \mathrm{C}$ for $45 \mathrm{~s}$, and $72^{\circ} \mathrm{C}$ for $60 \mathrm{~s}$; followed by $72^{\circ} \mathrm{C}$ for $10 \mathrm{~min}, 10^{\circ} \mathrm{C}$ until halted by user. The second PCR with NS31AM1(soil) (SIMON et al., 1992) or NS31-AMDGR 
Table 2 - Sequences primers of soil and root samples collected from Bijie and Libo sites in the study.

\begin{tabular}{lrrr}
\hline Primer pairs & \multicolumn{1}{c}{ Sequence $\left(5^{\prime} \rightarrow 3^{\prime}\right)$} & Target samples $^{\mathrm{b}}$ & Reference \\
\hline AML1(F) & ATCAACTTTCGATGGTAGGATAGA & SS and RS & (LEE et al., 2008) \\
AML2(R) & GAACCCAAACACTTTGGTTTCC & SS & (SIMON et al., 1992) \\
NS31(F) & TTGGAGGGCAAGTCTGGTGCC & & \\
AM1(R) & GTTTCCCGTAAGGCGCCGAA & RS & (SATO et al., 2005) \\
NS31(F) & TTGGAGGGCAAGTCTGGTGCC & & \\
AMDGR(R) & CCCAACTATCCCTATTAATCAT & \\
\hline
\end{tabular}

${ }^{\mathrm{a}} \mathrm{F}$, Forward primer; R, Reverse primer. ${ }^{\mathrm{b}} \mathrm{SS}$, soil samples; RS, root samples.

(root) (SATO et al., 2005) consisted of the following cycling conditions: $94^{\circ} \mathrm{C}$ for $5 \mathrm{~min} ; 32$ cycles at $94^{\circ} \mathrm{C}$ for $30 \mathrm{~s}, 58^{\circ} \mathrm{C}$ for $45 \mathrm{~s}$, and $72^{\circ} \mathrm{C}$ for $45 \mathrm{~s}$; followed by $72^{\circ} \mathrm{C}$ for $10 \mathrm{~min}, 10^{\circ} \mathrm{C}$ until halted by user. PCR products were detected by gel electrophoresis ( $2 \%$ agarose), and quantitative detection by the QuantiFluor $^{\mathrm{TM}}$-ST Blue Fluorescence Quantitative System (Promega, USA). Then, the corresponding percentage was mixed according to the volume of the sequencing of each sample.

\section{Sequencing}

The products were subjected to sequencing on Roche 454 GS FLX+ System (Roche Applied Science, Mannheim, Germany) at Shanghai Majorbio Bio-Pharm Technology Co.;Ltd. There were two reagents, Roche GS FLX Titanium emPCR Kits (Lib-L) and Roche GS FLX+ Sequencing Method Manual XLR70 kit, for emPCR amplification and Roche GS FLX+ sequencing, respectively.

\section{Bioinformatics}

All sequences obtained from this study were optimized using Usearch (EDGAR, 2013). Firstly, sequencing data of the various samples were differentiated by the sequence of barcode; and then the extracted data were preserved through standard flowgram format. Secondly, sequences with mean quality score $<20$, ambiguous nucleotides $>0$, homologous bases $>10$ and length $<200$ bp were removed. Thirdly, chimeras were detected using the 'UCHIME' method with better sensitivity (EDGAR et al., 2011) and removed.

Singletons obtained from the 454 pyrosequencing run were discarded using 'USEARCH' command. Unique sequences were extracted using 'fastx_uniques' command. And nonrepetitive sequences (without a single sequence) were clustered into operational taxonomic units (OTU) using 'UPARSE' method (EDGAR, 2013) with more than $97 \%$ similarity. The longest sequence of each OUT was chosen as a representative sequence. All representative sequences were compared with MaarjAM database (MOORA et al., 2011) by BLAST algorithm (parameter settings, 97\% similarity, coverage $>95 \%$, e-value $<1$ e-50) in July 2016. The alignment results of same sequence were regarded as the same virtual taxon (VT). However, some VTs came into being Norank at the genus level. Therefore, a new comparison was executed in October 2017. The virtual taxa of all samples were list in table 3 .

\section{Statistical analysis}

In community ecology, $\alpha$-diversity index can reflect the abundance and diversity of microbial communities. For comparing and analyzing $\alpha$-diversity between samples, the Shannon-Wiener diversity index of AMF in soils and roots was estimated in Mothur (SCHLOSS et al., 2018) and was calculated with the 'summary.single', 'collect. single', and 'rarefaction.single' commands.

The relative abundance was determined by the ratios between VT numbers of a genus and total VT numbers in an AM fungi community. The numbers of the unique and common VTs in the soils and roots were run using the R Programming Language.

Means and standard deviations of data were calculated in Excel 2013. The analysis of variance (ANOVA) was based on Duncan's new multiple range method in SPSS 16.0 software. To compare the soils collected at both sites, soil characteristics were tested using paired $t$-tests. Statistical significance was determined at a $95 \%$ confidence level $(P<0.05)$. Pearson's correlation coefficients between soil physical and chemical properties, and AMF community composition and diversity were calculated with a two-tailed test that was implemented in SPSS 16.0 software. There were 
Table 3 - Virtual taxon species of arbuscular mycorrhizal fungi in all root and soil samples collected from Bijie and Libo sites in the study.

\begin{tabular}{|c|c|c|c|}
\hline Order & Family & Genus & VT Species \\
\hline \multirow[t]{3}{*}{ Archaeosporales } & Ambisporaceae & Ambispora & VTX00242(a,b,c,d),VTX00283(b,c,d) \\
\hline & Archaeosporaceae & Archaeospora & VTX00051(b,c,d);VTX00004(a,c),VTX00008(c,d);VTX00245(a) \\
\hline & Acaulosporaceae & Acaulospora & VTX00027(a,b),VTX00044(a,b),VTX00048(a,b);VTX00328(b),VTX00024(d) \\
\hline \multirow[t]{2}{*}{ Diversisporales } & Diversisporaceae & Diversispora & VTX00061(a,b);VTX00054(b),VTX00058(b), VTX00263(b),VTX00300(b) \\
\hline & & Redeckera & VTX00262(a,b) \\
\hline \multirow[t]{2}{*}{ Glomerales } & Glomeraceae & Glomus & $\begin{array}{l}\text { VTX00053(a,b,c,d), VTX00063(a,b,c,d), VTX00067(a,b,c,d), } \\
\text { VTX00069(a,b,c,d), VTX00072(a,b,c,d), VTX00086(a,b,c,d), } \\
\text { VTX00093(a,b,c,d), VTX00105(a,b,c,d), VTX00111(a,b,c,d), } \\
\text { VTX00127(a,b,c,d), VTX00137(a,b,c,d), VTX00140(a,b,c,d), } \\
\text { VTX00156(a,b,c,d), VTX00167(a,b,c,d), VTX00175(a,b,c,d), } \\
\text { VTX00188(a,b,c,d), VTX00193(a,b,c,d), VTX00202(a,b,c,d), } \\
\text { VTX00211(a,b,c,d), VTX00213(a,b,c,d), VTX00217(a,b,c,d), } \\
\text { VTX00222(a,b,c,d), VTX00295(a,b,c,d), VTX00326(a,b,c,d); VTX00287(a,b,c), } \\
\text { VTX00186(a,b,c), VTX00256(a,b,c), VTX00342(a,b,c), VTX00204(a,b,d); } \\
\text { VTX00121(a,b), VTX00136(a,b), VTX00212(a,b), VTX00268(a,b), } \\
\text { VTX00323(a,b), VTX00179(c,d), VTX00225(c,d), VTX00313(c,d), } \\
\text { VTX00322(c,d), VTX00327(c,d), VTX00332(c,d), VTX00343(c,d), } \\
\text { VTX00165(a,c), VTX00197(a,c), VTX00235(b,c); VTX00107(a), VTX00304(a) } \\
\text { VTX00319(a), VTX00123(c), VTX00293(c), VTX00301(c), VTX00324(c), } \\
\text { VTX00073(b), VTX00100(b), VTX00120(b), VTX00178(b) }\end{array}$ \\
\hline & Claroideoglomeraceae & Claroideoglomus & VTX00276(a,b,c,d);VTX00237(a,b,c);VTX00278(a), VTX00340(a) \\
\hline Paraglomerales & Paraglomeraceae & Paraglomus & $\begin{array}{l}\text { VTX00001(a,b,c,d),VTX00239(a,b,c,d),VTX00281(a,b,c,d),VTX00308(a,b,c,d); } \\
\text { VTX00238(b,c,d),VTX00336(b,c,d);VTX00335(a,c) }\end{array}$ \\
\hline
\end{tabular}

a,b,c and d represent the samples collected from soils at Bijie and Libo sites, and roots at Bijie and Libo sites, respectively.

16 paired samples for either the soil samples or the root samples in relation to the AMF assessments at Bijie site, while 15 paired samples at Libo site.

\section{RESULTS}

\section{Soil chemical properties}

The physical and chemical properties of soil at Bijie and Libo sites were shown in table 4. With the soil depth increase, almost the values of all indices decreased, although there were a few exceptions such as TK, AK, and T-Ca. Compared to the depth variation, the seasonal variation of these chemical indices was irregular. Specifically, the contents of $\mathrm{OM}, \mathrm{TCa}, \mathrm{TN}$, TP, TK and AK were highest and AP was lowest in January at Bijie site. However, the highest values of all indices occurred in April at Libo site.

\section{Arbuscular mycorrhizal fungi composition in different habitats}

83 VTs were detected from the soil and root samples with the high-throughput sequencing analysis, which belonged to 3 classes (Archaeosporomycetes; Glomeromycetes; Paraglomeromycetes), 4 orderes (Archaeosporales; Diversisporales; Glomerales;Paraglomerales),
7 families (Ambisporaceae, Archaeosporaceae; Acaulosporaceae, Diversisporaceae;,Claroideog lomeraceae, Glomeraceae; Paraglomeraceae), 8 genera (Ambispora, Archaeospora; Acaulospora, Diversisporav, Redeckera; Claroideoglomus, Glomus; Paraglomus) (Table 3).

There were differences in relative abundance of species identified from the eight genera between Bijie and Libo sites or between the soil and root samples at the two sites (Figure 2). Specifically, the abundance of species from the genus Glomus in the soil at Bijie stie was $69.6 \%$, more than $65 \%$ at Libo site. In root samples at Bijie site, the abundance of species from the genus Glomus was $75.0 \%$, also more than $72.7 \%$ at Libo site. The species of genera Glomus in roots and soil were dominant species among the eight genera (Table 3). Conversely, the abundance of species from the genus Paraglomus, ranging from $8 \%$ to $15 \%$, in soil and root samples at Libo site was slightly lower than Bijie site,. Especially, the genus Diversisporav had $8 \%$ of the abundance of species in soil samples at Libo site, far than abundance in soil and root samples at Bijie site, and in root samples at Libo site. The abundance of species from other genera was all lower than $8 \%$. The genus Redeckera was even less than $2 \%(1.8 \%$ 
Table 4 - Physical and chemical properties of soil at different depths and seasons at Bijie (in front of slash) and Libo sites (behind slash)

\begin{tabular}{|c|c|c|c|c|c|c|c|c|c|}
\hline Month & Depth $(\mathrm{cm})$ & $\mathrm{pH}$ & $\mathrm{OM}(\mathrm{g} / \mathrm{kg})$ & $\mathrm{TN}(\mathrm{g} / \mathrm{kg})$ & $\mathrm{TP}(\mathrm{g} / \mathrm{kg})$ & $\mathrm{TK}(\mathrm{g} / \mathrm{kg})$ & $\mathrm{AP}(\mathrm{mg} / \mathrm{kg})$ & $\mathrm{AK}(\mathrm{mg} / \mathrm{kg})$ & $\mathrm{TCa}(\mathrm{g} / \mathrm{kg})$ \\
\hline & $0-10$ & $7.07 / 6.74$ & $30.69 / 24.1$ & $3.78 / 2.90$ & $0.44 / 0.79$ & $11.1 / 4.00$ & $1.50 / 0.99$ & $64.9 / 24.4$ & $10.9 / 2.19$ \\
\hline \multirow[t]{4}{*}{ Winter } & $10-20$ & $6.94 / 7.02$ & $27.59 / 19.5$ & $3.01 / 2.42$ & $0.59 / 0.56$ & $9.71 / 3.97$ & $0.87 / 0.71$ & $38.8 / 13.6$ & $9.99 / 1.21$ \\
\hline & $20-30$ & $7.34 / 7.06$ & $23.25 / 13.0$ & $2.77 / 2.07$ & $0.55 / 0.43$ & $10.6 / 4.08$ & $0.46 / 0.14$ & $17.3 / 13.3$ & $11.0 / 1.08$ \\
\hline & $30-40$ & $7.25 / 7.06$ & $14.84 / 11.8$ & $1.88 / 2.09$ & $0.44 / 0.11$ & $10.5 / 4.43$ & $0.49 / 0.25$ & $32.6 / 17.0$ & $9.16 / 0.11$ \\
\hline & $0-10$ & $7.16 / 6.82$ & $23.02 / 25.3$ & $2.68 / 3.39$ & $0.47 / 0.96$ & $10.8 / 5.53$ & 7.77/11.9 & $59.4 / 17.0$ & $5.85 / 4.31$ \\
\hline \multirow[t]{4}{*}{ Spring } & $10-20$ & $7.25 / 7.01$ & $23.61 / 23.4$ & $2.56 / 2.44$ & $0.36 / 0.77$ & $9.41 / 4.89$ & $7.67 / 9.10$ & $38.9 / 19.0$ & $4.60 / 5.40$ \\
\hline & $20-30$ & $7.50 / 7.12$ & $17.63 / 22.0$ & $1.91 / 2.60$ & $0.37 / 0.71$ & $9.80 / 5.10$ & $7.47 / 11.7$ & $38.3 / 18.6$ & $4.83 / 6.03$ \\
\hline & $30-40$ & $7.61 / 7.39$ & $17.68 / 23.4$ & $1.50 / 1.59$ & $0.33 / 0.63$ & $10.2 / 4.36$ & $6.83 / 10.1$ & $43.9 / 16.0$ & $2.89 / 6.10$ \\
\hline & $0-10$ & $6.59 / 6.51$ & $25.29 / 25.2$ & $3.04 / 3.04$ & $0.22 / 0.24$ & $10.2 / 4.36$ & $7.03 / 8.47$ & $34.6 / 22.6$ & $10.9 / 7.60$ \\
\hline \multirow[t]{4}{*}{ Summer } & $10-20$ & $6.59 / 6.63$ & $21.92 / 24.4$ & $2.40 / 3.16$ & $0.22 / 0.32$ & $10.0 / 5.25$ & $8.74 / 6.23$ & $27.6 / 12.3$ & $9.99 / 6.14$ \\
\hline & $20-30$ & $6.77 / 6.47$ & $20.52 / 21.9$ & $2.15 / 2.55$ & $0.21 / 0.38$ & $9.95 / 5.12$ & $11.83 / 10.4$ & $20.6 / 18.0$ & $11.0 / 14.3$ \\
\hline & $30-40$ & $6.83 / 6.51$ & $19.35 / 22.7$ & $1.83 / 2.99$ & $0.23 / 0.38$ & $10.8 / 5.21$ & $7.26 / 6.70$ & $22.6 / 3.00$ & $9.16 / 2.52$ \\
\hline & $0-10$ & $6.24 / 6.52$ & $25.85 / 29.3$ & $2.94 / 3.95$ & $0.09 / 0.08$ & $10.1 / 5.24$ & $14.1 / 9.83$ & $39.8 / 29.5$ & $5.00 / 6.96$ \\
\hline \multirow[t]{3}{*}{ Autumn } & $10-20$ & $6.28 / 6.61$ & $10.88 / 25.7$ & $1.77 / 3.17$ & $0.18 / 0.35$ & $11.0 / 5.50$ & $7.83 / 9.90$ & $29.6 / 22.0$ & $2.92 / 14.1$ \\
\hline & $20-30$ & $6.31 / 6.54$ & $10.37 / 13.9$ & $1.71 / 1.83$ & $0.16 / 0.17$ & $9.92 / 5.66$ & $5.77 / 7.50$ & $26.0 / 13.3$ & $3.18 / 4.32$ \\
\hline & $30-40$ & $6.39 /$ & $13.44 /$ & $1.41 /$ & $0.16 /$ & $12.2 /$ & $6.77 /$ & $25.0 /$ & $3.27 /$ \\
\hline
\end{tabular}

and $1.7 \%$ in the soil at Bijie and Libo sites; $0.0 \%$ and $0.0 \%$ in the root at the two sites).

At the level of species, 56 VTs and 60 VTs were observed in the soil samples at Bijie and Libo sites, respectively (Figure 3 ). There were 46 common species among all these species in these soil samples. In the root samples at Bijie and Libo sites, 56 VTs and 44 VTs were found. The number of the common species was 42 in the root samples.

\section{Arbuscular mycorrhizal fungi diversity variation at different soil depths in four seasons \\ Shannon-Wiener Wiener index of AMF} in both soil and root samples decreased with an increase of soil depth (Figure 4). Shannon-Wiener index in both the soil and root samples showed that the diversity of AMF, was higher at Bijie site than Libo site. Also, more genera and species in the soil or root samples collected in October were tested than other months (Table 5). The seasonal variation in the number of TVs in both the soil and root samples was also significant.

\section{Relationships between arbuscular mycorrhizal fungi diversity and soil properties}

Shannon-Wiener index of AMF in soils presented a significantly positive correlation with $\mathrm{OM}$ and TN in soil samples at Bijie site (Table 6). There was a significantly negative correlation of ShannonWiener index of AMF in soils with $\mathrm{pH}$ in soil samples at Libo site. In the root samples, Shannon-
Wiener index of AMF showed a significantly negative correlation with $\mathrm{pH}$ and $\mathrm{TCa}$ in soils at Bijie site. However, there was a significantly positive correlation between Shannon-Wiener index of AMF in the root samples at Libo site and AK content in the soil. Based on combined analysis of two sites, significant correlations occurred between ShannonWiener index of AMF and TP, TK, AK or TCa in soils, and between Shannon-Wiener index of AMF in soils and TK or AK in soils.

\section{DISCUSSION}

Time and temperature effects on the composition and diversity of arbuscular mycorrhizal fungi after returning cropland to forest

The soil and root samples were collected from the mulberry fields at Bijie and Libo sites to test the AMF diversity. The mulberry fields at Bijie and Libo sites had respectively lasted for ten and one years after returning cropland to forest. Therefore, time affecting AMF diversity in soil and root samples after returning cropland to forest is obviously different. The result indicated that Shannon-Wiener index of AMF in the soil and root samples at Bijie site was higher than Libo site. The number of VTs in the root samples of mulberry, which directly affected the absorption of soil moisture and nutrient from soils, at Bijie site was also more than Libo site; although the opposite results were found in the soil samples. In the study field, those results firstly showed that the time effect 


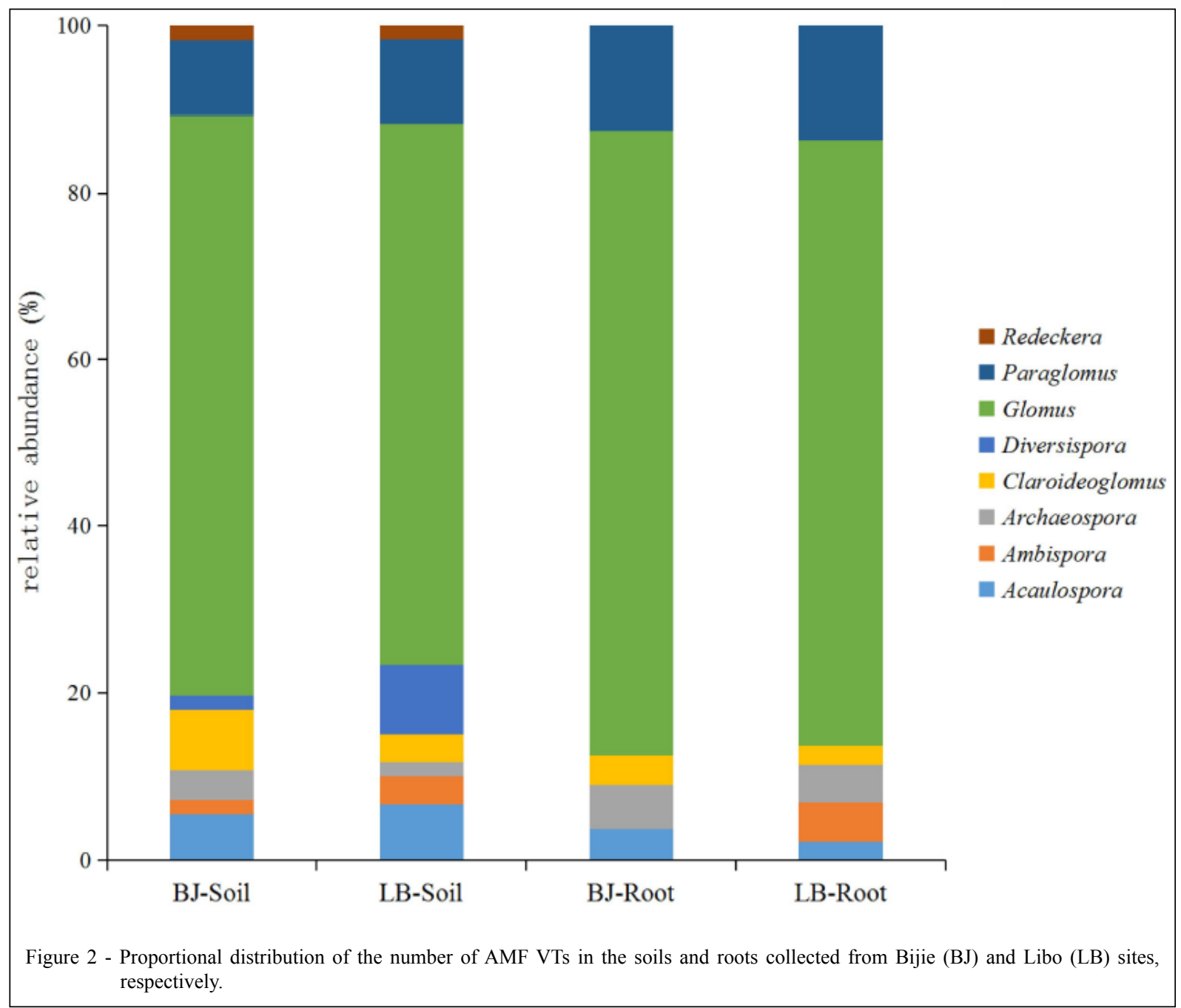

on the AMF diversity in the habitats after returning cropland to forest is significant. In the composition of AMF, the dominant AMF genera Glomus at Bijie site accounted for $69.6 \%$ of the number of all TVs, which was higher than $65.0 \%$ at Libo site. The species of genera Glomus were also dominant among the eight genera (Table 3). The present results were in accordance with other previous reports on the dominant genus and species of AMF communities in different ecosystems (LI et al., 2010; WANG et al., 2014; XIANG et al., 2014). Thus, returning cropland to forest as a measure is beneficial to restoration of the AMF diversity in the soil, and the root systems of mulberry. Our data also confirmed that most $(>65$ $\%$ ) of AMF in soil and root samples belong to the Glomeraceae, which has reported in the previous studies (ZHANG et al., 2004; WANG et al., 2015).
The previous reports indicated that the increased land use intensity has a great effect on a decrease in AMF species richness (XIANG et al., 2014; CICCOLINI et al., 2016). Time after returning cropland to forest at Bijie has been for ten years, and at Libo only for one year, which means that the land use intensity at Bijie is lower than at Libo. Thus, the results of the land use intensity affecting the AMF diversity in this study are consistent with the previous studies (XIANG et al., 2014; CICCOLINI et al., 2016).

Climate, e.g. temperature and precipitation, is the main drivers of species diversity and composition (KLEIN et al., 2004; XIANG et al., 2014). WANG et al. (2014) found that higher AMF richness occurred in the rainy season from July to October. In the stage, high soil temperature and moisture favor the growth and population establishment of AMF. In 


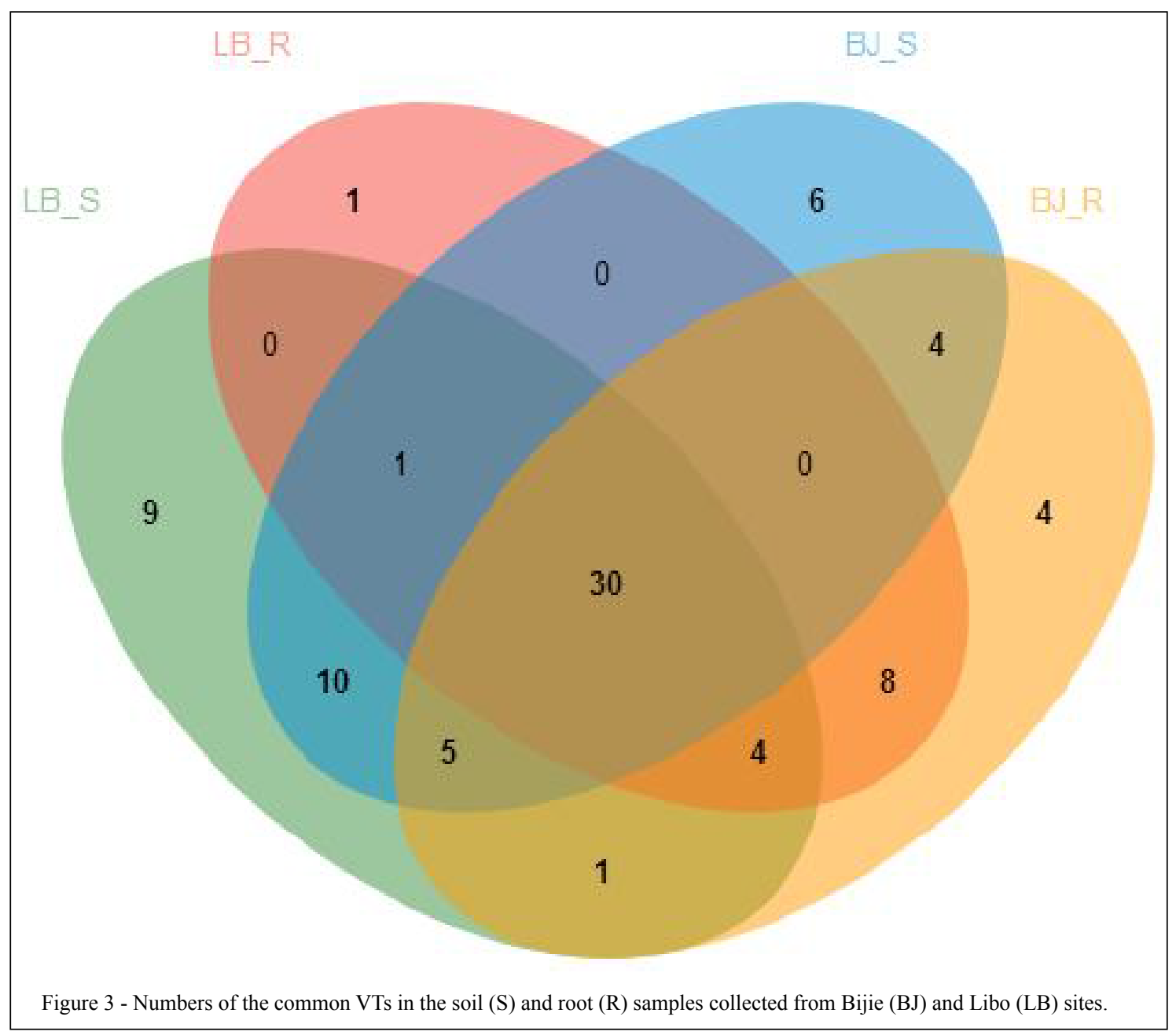

this study, the seasonal variation in AMF diversity has observed at both Bijie and Libo sites. Moreover, the most diverse AMF occurred in Oct, a warm and wet month, which agrees with a previous report in southwest China (LI et al., 2005). Additionally, the period of May to October was the growth stages for mulberry, and many organic nutrients from the root systems of mulberry could nourish, AMF, resulting in high diversity of AMF besides the positive effects of soil temperature and moistures (WANG et al., 2014; TEIXEIRA-RIOS et al., 2018).

The effect of soil properties on arbuscular mycorrhizal fungi diversity

We explored the relationships between AMF in soils or roots and soil chemical properties. The correlation analysis given in table 4 showed that Shannon-Wiener index of AMF in soil or root samples had significant correlations with $\mathrm{pH}$,
OM, TN, TP, TK, AK, or TCa in soils. However, the correlations varied with changes of sites, and combined analysis showed different results about the correlations from separate analysis at two sites. Those results indicate that relationship between soil properties and AMF diversity is complex, which confirms previous work (BÖRSTLER et al., 2006; GARCÍA et al., 2009; QURROGA et al., 2017). It is not surprising that Shannon-Wiener index of AMF in both soil and root samples have different correlations with soil properties because there are other factors affecting the relationships between Shannon-Wiener index of AMF and soil chemical properties (VAN DER HEIJDEN, 2004; VAN DER HEIJDEN et al., 2006). These factors need to be further studied and quantified. In fact, in the study, some indirect evidence supported significant correlations of AMF diversity with soil chemical properties. Specifically, in table 4, the values of almost all the indices of soil properties 

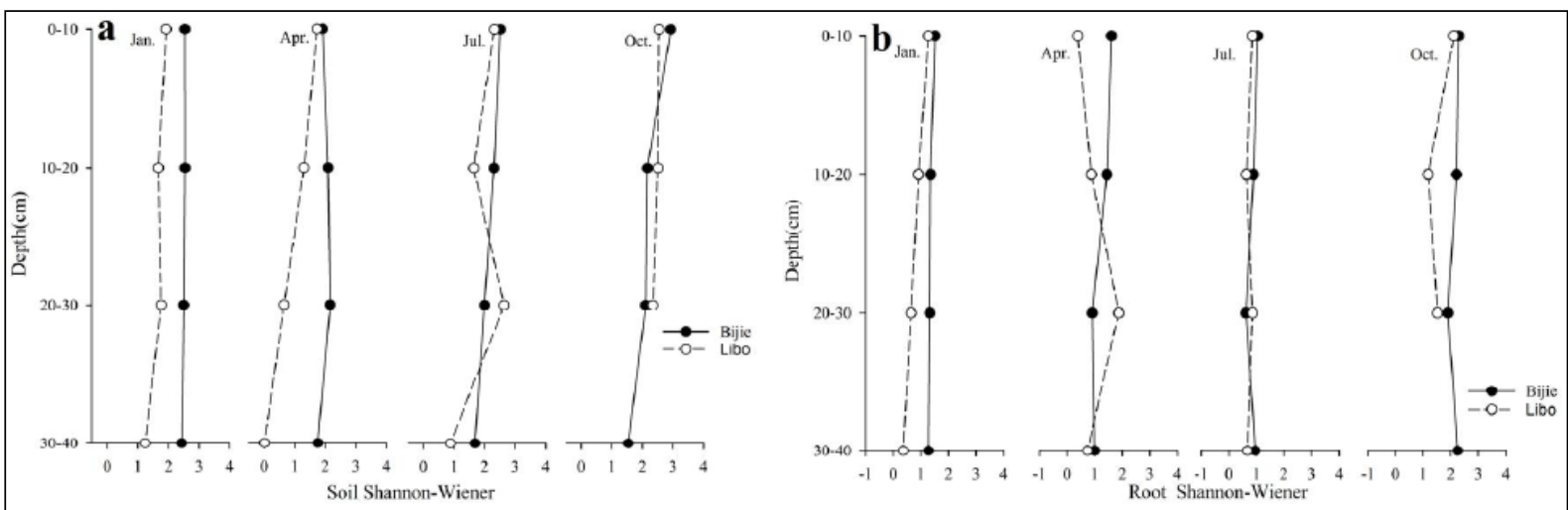

Figure 4 - AMF diversity with the variation of soil depths. a: soil. b: plant root. The solid circle represents samples collected from Bijie site; the hollow circle represents the samples collected from Libo site. Using one-to-one correspondence method, the mulberry root wasn't found at depth of $30-40 \mathrm{~cm}$ in Oct.

decreased with increased soil depths at Bijie site. Correspondingly, the Shannon-Wiener index of AMF in soil and root samples also decreased (Figure 4). The results were new evidences directly showing the effects of resource availability on diversity. In table 4 , the values of the indices of soil properties also changed with different seasons. For example, $\mathrm{pH}$ was lowest and $\mathrm{AK}$ was highest in autumn at Libo site. Consequently, the AMF diversity was highest in autumn, which was consistent with the results in table 6 . Those results indicated that soil properties are the important reason for the AMF diversity. So, we infer that the change of soil properties in the habitats after returning cropland to forest or the management of mulberry planting plays a positive role in the variation of AMF diversity.

The effect of arbuscular mycorrhizal fungi on vegetation restoration in rocky desertification land

In karst rocky desertification land, several reports have indicated that AMF can improve photosynthetic capacity, increase water use efficiency, promote transplant survival rate in mulberry (CHEN et al., 2014; PIAO et al., 2016).

Table 5 - Biological groups of arbuscular mycorrhizal fungi in both soil and root samples collected from Bijie and Libo sites in different seasons.

\begin{tabular}{|c|c|c|c|c|c|c|}
\hline Site & Sample & Season & Order & Family & Genus & Species \\
\hline & & Jan & 3 & 5 & 5 & 42 \\
\hline & root & Apr & 3 & 5 & 5 & 30 \\
\hline & & Jul & 2 & 3 & 3 & 24 \\
\hline \multirow[t]{8}{*}{ Bijie } & & Oct & 3 & 5 & 5 & 47 \\
\hline & & Jan & 3 & 4 & 4 & 43 \\
\hline & soil & Apr & 3 & 4 & 4 & 39 \\
\hline & & Jul & 4 & 6 & 7 & 43 \\
\hline & & Oct & 4 & 6 & 6 & 44 \\
\hline & & Jan & 4 & 5 & 5 & 31 \\
\hline & root & Apr & 3 & 3 & 3 & 18 \\
\hline & & Jul & 2 & 2 & 2 & 15 \\
\hline \multirow[t]{5}{*}{ Libo } & & Oct & 3 & 5 & 5 & 35 \\
\hline & & Jan & 3 & 4 & 4 & 37 \\
\hline & soil & Apr & 3 & 5 & 5 & 36 \\
\hline & & Jul & 3 & 5 & 6 & 41 \\
\hline & & Oct & 4 & 7 & 7 & 48 \\
\hline
\end{tabular}

Ciência Rural, v.48, n.10, 2018. 
Table 6 - Coefficients of the correlation between Shannon-Wiener index of AMF in both soil and root samples and the properties of soil samples from Bijie and Libo sites.

\begin{tabular}{|c|c|c|c|c|c|c|c|c|}
\hline Shannon-Wiener index & $\mathrm{pH}$ & $\mathrm{OM}$ & $\mathrm{TN}$ & $\mathrm{TP}$ & TK & AP & $\mathrm{AK}$ & $\mathrm{TCa}$ \\
\hline Soils at: Bijie site & -0.124 & $0.540^{*}$ & $0.716^{* *}$ & 0.178 & -0.37 & -0.144 & 0.184 & 0.415 \\
\hline Libo site & $-0.761^{* *}$ & 0.129 & 0.456 & -0.409 & 0.25 & 0.006 & 0.445 & -0.006 \\
\hline Roots at: Bijie site & $-0.564^{*}$ & -0.248 & -0.029 & -0.300 & 0.458 & 0.087 & 0.122 & $-0.578^{*}$ \\
\hline Libo site & -0.323 & 0.349 & 0.289 & -0.258 & 0.221 & 0.275 & $0.563^{*}$ & 0.447 \\
\hline Combined Shannon-Wiener index of AMF in soils at two sites & -0.322 & 0.185 & 0.341 & $-.371^{*}$ & $0.406^{*}$ & -0.064 & $0.437^{*}$ & $0.493^{* *}$ \\
\hline Combined Shannon-Wiener index of AMF in roots at two sites & -0.349 & -0.052 & -0.003 & -0.311 & $0.449^{*}$ & 0.155 & $0.414^{*}$ & -0.027 \\
\hline
\end{tabular}

${ }^{*}$ significance level: $\mathrm{P}<0.05 ;{ }^{* *}$ significance level: $\mathrm{P}<0.01$.

After AMF inoculation and colonization, the mulberry growth, leaf quality, biomass and alkaline-tolerance are obviously improved (KASHYAP et al., 2004; KUNJUPILLAI, 2009; SHI et al., 2016). In this study, we also discovered that the differences in the AMF composition and diversity occurred between Bijie and Libo sites which lasted for ten and one years after returning cropland to forest. Although the proprietary species was not so obviously, high diversity of AMF in roots occurred at Bijie site for a long time after returning cropland to forest. This is good news for the vegetation restoration in rocky desertification land, because, after all, high diversity of AMF can result in good ecosystem functions for karst desertification land. Moreover, we observed some genera, such as Glomus, Paraglomus and Archaeospora, which were dominated in the roots of mulberry. Their dominance is biologically dependent on their high adaption to karst habitats. Thus, we may inoculate these genera or VTs in these genera to the roots of mulberry or other plants to promote plant growth for control of karst desertification.

\section{CONCLUSION}

There are differences in AMF composition and diversity between the sites experiencing different time courses after returning cropland to forest. AMF diversity is higher in the roots of mulberry at Bijie site experiencing ten years after returning cropland to forest than Libo site only one year. The genera Glomus, Paraglomu, and Archaeospora greatly dominate among all AMF genera in the roots of mulberry. Shannon-Wiener index of AMF in soil and root samples decreased with increasing soil depths, and correspondingly, soil nutrient contents in soils also decreased. Soil chemical properties are related to the diversity index of AMF. There are an interactive effect of time, climate, and resource availability on the AMF diversity and composition. The inoculation and cultivation of the dominant species of AMF selected from the study in the mulberry roots are worthwhile research in further to develop the new techniques that are used by scientists to cope with the restoration of dry karstic habitats.

\section{ACKNOWLEDGMENTS}

This work was supported by National Natural Science Foundation of China (31460225), and National sericulture technology system of China (CARS-18-SYZ21). We thank Shanghai Majorbio Bio-Pharm Technology Co.; Ltd for the support with equipments. We also thank Mr Guihua Peng, Miss Fangfang Liao, Miss Fang Zhang, Mr Yongping Wang, Mr Xiaohong Wang and Mr Zehu Luo for their help with the sample collection.

\section{DECLARATION OF CONFLICTING INTERESTS}

The authors declare no conflict of interest. The founding sponsors had no role in the design of the study; in the collection, analyses, or interpretation of data; in the writing of the manuscript, and in the decision to publish the results.

\section{REFERENCES}

BEVER, J.D. Host-specificity of AM fungal population growth rates can generate feedback on plant growth. Plant \& Soil, v.244, n.2, p.289-290, 2002. Available from: <http://dx.doi. org/10.1023/A:1020221609080>. Accessed: Apr. 30, 2018. doi: 10.1023/A:1020221609080.

BOWMAN, R.A. A rapid method to determine total phosphorus in soils. Soil Science Society of America Journal, v.52, n.5, p.1301-1304, 1988. Available from: <http://dx.doi.org/10.2136/ss saj1988.03615995005200050016x>. Accessed: Apr. 30, 2018. doi: 10.2136/sssaj1988.03615995005200050016x.

BÖRSTLER, B. et al. Species composition of arbuscular mycorrhizal fungi in two mountain meadows with differing management types and levels of plant biodiversity. Biology and 
Fertility of Soils, v.42, n.4, p.286-298, 2006. Available from: $<$ http://dx.doi.org/10.1007/s00374-005-0026-9>. Accessed: Apr. 30, 2018. doi: 10.1007/s00374-005-0026-9.

CHEN, K. et al. Contribution of arbuscular mycorrhizal inoculation to the growth and photosynthesis of mulberry in karst rocky desertification area. Applied Mechanics \& Materials, v.488489, p.769-773, 2014. Available from: <http://dx.doi.org/10.4028/ www.scientific.net/AMM.488-489.769>. Accessed: Apr. 30, 2018. doi: 10.4028/www.scientific.net/AMM.488-489.769.

CICCOLINI, V. et al. Land-use intensity and host plant simultaneously shape the composition of arbuscular mycorrhizal fungal communities in a Mediterranean drained peatland. FEMS Microbiology Ecology, v.92, n.12, p.fiw186, 2016. Available from: < https://doi.org/10.1093/femsec/fiw186>. Accessed: Apr. 30, 2018. doi: 10.1093/femsec/fiw186.

EDGAR, R. C. UPARSE, highly accurate OTU sequences from microbial amplicon reads. Nature Methods, v.10, n.10, p.996-998, 2013. Available from: <http://dx.doi.org/10.1038/nmeth.2604>. Accessed: Apr. 30, 2018. doi: 10.1038/nmeth.2604.

EDGAR, R. C., et al. UCHIME improves sensitivity and speed of chimera detection. Bioinformatics, v.27, n.16, p.2194-2200, 2011. Available from: <http://dx.doi.org/10.1093/bioinformatics/btr381>. Accessed: Apr. 30, 2018. doi: 10.1093/bioinformatics/btr381.

GARCÍA, I.V. et al. Arbuscular mycorrhizal fungi and plant symbiosis under stress conditions, ecological implications of drought, flooding and salinity. Applied Mycology, p.17-37, 2009. Available from: $<$ https://www.researchgate.net/publication/236870186_I Garcia_and_R_Mendoza_Chapter_2_Arbuscular_mycorrhizal_ fungi_and_plant_symbiosis_under_stress_conditions_ecological_ implications of drought flooding and salinity En Applied Mycology_M_Rai_y_PD_Bridge $>$. Accessed: Apr. 30, 2018.

GUO, F. et al. Evolution of major environmental geological problems in karst areas of southwestern china. Environmental Earth Sciences, v.69, n.7, p.2427-2435, 2013. Available from: $<$ http://dx.doi.org/10.1007/s12665-012-2070-8>. Accessed: Apr. 30, 2018. doi: 10.1007/s12665-012-2070-8.

GUO, K. et al. Ecological adaptation of plants and control of rocky desertification on karst region of Southwest China. Chinese Journal of Plant Ecology, v.35, n.10, p.991-999, 2011. Available from: $<$ http://dx.doi.org/10.3724/SP.J.1258.2011.00991>. Accessed: Apr. 30, 2018. doi: 10.3724/SP.J.1258.2011.00991.

HASELWANDTER, K.; BOWEN, G.D. Mycorrhizal relations in trees for agroforestry and land rehabilitation. Forest Ecology \& Management, v.81, n.1-3, p.1-17, 1996. Available from: <http:// dx.doi.org/10.1016/0378-1127(95)03661-X>. Accessed: Apr. 30, 2018. doi: 10.1016/0378-1127(95)03661-X.

HOEKSEMA, J.D. et al. A meta-analysis of context-dependency in plant response to inoculation with mycorrhizal fungi. Ecology Letters, v.13, n.3, p.394-407, 2010. Available from: <http://dx.doi. org/10.1111/j.1461-0248.2009.01430.x>. Accessed: Apr. 30, 2018. doi: $10.1111 /$ j.1461-0248.2009.01430.x.

KASHYAP, S. et al. Role of bioinoculants in development of saltresistant saplings of Morus alba (var. sujanpuri) in vivo. Scientia Horticulturae, v.100, n.1-4, p.291-307, 2004. Available from: $<$ http://dx.doi.org/10.1016/j.scienta.2003.09.001>. Accessed: Apr. 30, 2018. doi: 10.1016/j.scienta.2003.09.001.
KATIYAR, R.S. et al. Vesicular-arbuscular mycorrhizal association in mulberry. Current Science, v.58, n.12, p.461-464, 1989. Available from: <http://www.currentscience.ac.in/Downloads/ article_id_058_08_0461_0464_0.pdf>. Accessed: Apr. 30, 2018.

KLEIN, J.A. et al. Experimental warming causes large and rapid species loss, dampened by simulated grazing, on the Tibetan Plateau. Ecology Letters, v.7, n.12, p.1170-1179, 2004. Available from: $<$ http://dx.doi.org/10.1111/j.1461-0248.2004.00677.x>. Accessed: Apr. 30, 2018. doi: 10.1111/j.1461-0248.2004.00677.x.

KOIDE, R.T. Functional complementarity in the arbuscular mycorrhizal symbiosis. New Phytologist, v.147, n.2, p.233235, 2000. Available from: <http://dx.doi.org/10.1046 /j.1469-8137.2000.00710.x>. Accessed: Apr. 30, 2018. doi: 10.1046/j.1469-8137.2000.00710.x.

KUNJUPILLAI, V. Approaches for enhancing salt tolerance in mulberry (Morus L.)-A review. Plant Omics Journal of Plant Molecular Biology \& Omics, v.2, n.1, p.41-59, 2009. Available from: <http://www.pomics.com/Vijayan January2009_2_1_41_59.pdf>. Accessed: Apr. 30, 2018.

LEE, J. et al. Improved PCR primers for the detection and identification of arbuscular mycorrhizal fungi. Fems Microbiology Ecology, v.65, n.2, p.339-349, 2008. Available from: <http:// dx.doi.org/10.1111/j.1574-6941.2008.00531.x>. Accessed: Apr. 30, 2018. doi: 10.1111/j.1574-6941.2008.00531.x.

LEUNG, H.M. et al. Survival strategies of plants associated with arbuscular mycorrhizal fungi on toxic mine tailings. Chemosphere, v.66, n.5, p.905-915, 2007. Available from: $<\mathrm{http}: / /$ dx.doi.org/10.1016/j.chemosphere.2006.06.037>. Accessed: Apr. 30, 2018. doi: 10.1016/j.chemosphere.2006.06.037.

LI, L. et al. Molecular diversity of arbuscular mycorrhizal fungi and their distribution patterns related to host-plants and habitats in a hot and arid ecosystem, southwest China. FEMS Microbiology Ecology, v.71, n.3, p.418-427, 2010. Available from: $<$ https://doi. org/10.1111/j.1574-6941.2009.00815.x>. Accessed: Apr. 30, 2018. doi: $10.1111 / \mathrm{j} .1574-6941.2009 .00815 . x$.

LI, L. et al. Seasonality of arbuscular mycorrhizal symbiosis and dark septate endophytes in a grassland site in southwest China. FEMS Microbiology Ecology, v.54, n.3, p.367-373, 2005. Available from: <https://doi.org/10.1016/j.femsec.2005.04.011>. Accessed: Apr. 30, 2018. doi: 10.1016/j.femsec.2005.04.011.

LI, Y.B. et al. The relations between land use and karst rocky desertification in a typical karst area, China. Environmental Geology, v.57, n.3, p.621-627, 2009. Available from: <http:// dx.doi.org/10.1007/s00254-008-1331-z>. Accessed: Apr. 30, 2018. doi: $10.1007 / \mathrm{s} 00254-008-1331-\mathrm{z}$.

LIAO, C.F.H. Tellurium as catalyst in semimicro Kjeldahl method for total nitrogen determination. Journal of the Association of Official Analytical Chemists, v.65, n.4, p.786-790, 1982.

MAHERALI, H.; KLIRONOMOS, J.N. Influence of phylogeny on fungal community assembly and ecosystem functioning. Science, v.316, n.5832, p.1746-1748, 2007. Available from: <http://dx.doi. org/10.1126/science.1143082>. Accessed: Apr. 30, 2018. doi: $10.1126 /$ science. 1143082 .

MARSHALL, G.B.; West, T.S. Determination of traces of calcium, magnesium, iron and nickel in aluminium salts by 
atomic-absorption spectrophotometry with a microwave-excited source and hollow-cathode lamps. Talanta, v.14, n.7, p.823, 1967. Available from: <http://dx.doi.org/10.1016/0039-9140(67)801048>. Accessed: Apr. 30, 2018. doi: 10.1016/0039-9140(67)80104-8.

MOORA, M. et al. Alien plants associate with widespread generalist arbuscular mycorrhizal fungal taxa: evidence from a continentalscale study using massively parallel 454 sequencing. Journal of Biogeography, v.38, n.7, p.1305-1317, 2011. Available from: $<$ http://doi.org/10.1111/j.1365-2699.2011.02478.x>. Accessed: Apr. 30, 2018. doi: 10.1111/j.1365-2699.2011.02478.x.

MORGAN, A. J.; MORRIS, B. The accumulation and intracellular compartmentation of cadmium, lead, zinc and calcium in two earthworm species (Dendrobaena rubida and Lumbricus rubellus) living in highly contaminated soil. Histochemistry, v.75, n.2, p.269285, 1982. Available from: <https://doi.org/10.1007/BF00496017>. Accessed: Apr. 30, 2018. doi: 10.1007/BF00496017.

NATHAN GAMMON J. R. Determination of total potassium and sodium in sandy soils by flame photometer. Soil Science, v.71, n.3, p.211-214, 1951. Available from: <http://dx.doi. org/10.1097/00010694-195103000-00009>. Accessed: Apr. 30, 2018. doi: 10.1097/00010694-195103000-00009.

OLSEN S.R. et al. Estimation of available phosphorus in soils by extraction with sodium bicarbonate. United States Department of Agriculture. Circular, n.939, p.1-19, 1954 , Available from: $<$ http://dx.doi.org/10.2307/302397>. Accessed: Apr. 30, 2018. doi: $10.2307 / 302397$

PIAO, H. et al. Nutrient uptake by mulberry and Chinese prickly ash associated with arbuscular mycorrhizal fungi. Acta Geochimica, v.35, n.2, p.120-129, 2016. Available from: <http:// dx.doi.org/10.1007/s11631-016-0097-3>. Accessed: Apr. 30, 2018. doi: 10.1007/s11631-016-0097-3.

QIN, J. et al. Ecological issues of mulberry and sustainable development. Journal of Resources and Ecology, v.35, n.10, p.991-999, 2012. Available from: <http://dx.doi.org/10.5814/j. issn.1674-764x.2012.04.006>. Accessed: Apr. 30, 2018. doi: 10.5814/j.issn.1674-764x.2012.04.006.

QURROGA, G. et al. Enhanced drought stress tolerance by the arbuscular mycorrhizal symbiosis in a drought-sensitive maize cultivar is related to a broader and differential regulation of host plant aquaporins than in a drought-tolerant cultivar. Frontiers in Plant Science, n.8, p.1056, 2017. Available from: $<$ http://dx.doi. org/10.3389/fpls.2017.01056>. Accessed: Apr. 30, 2018. doi: $10.3389 /$ fpls. 2017.01056

RAJAGOPAL, D. et al. Occurrence of vesicular arbuscular mycorrhizal fungi in roots of Morus alba L. Current Science, v.58, n.12, p.687-689, 1989. Available from: $<$ http://www.currentscience. ac.in/Downloads/article_id_058_12_0687_0689_0.pdf $>$. Accessed: Apr. 30, 2018.

SATO, K. et al. A new primer for discrimination of arbuscular mycorrhizal fungi with polymerase chain reaction-denature gradient gel electrophoresis. Grassland Science, v.51, n.2, p.179-181, 2005. Available from: <http://dx.doi.org/10.1111/ j.1744-697X.2005.00023.X>. Accessed: Apr. 30, 2018. doi: 10.1111/j.1744-697X.2005.00023.x.

SCHLOSS, P. D. et al. Reducing the effects of PCR amplification and sequencing artifacts on $16 \mathrm{~S}$ rRNA-based studies. Plos
One, v.6, n.12, p.e 27310, 2011. Available from: <http://dx.doi. org/10.1371/journal.pone.0027310>. Accessed: Apr. 30, 2018. doi: 10.1371/journal.pone.0027310.

SEKIYA, K. Fractionation of inorganic phosphate. In: Committee of standard methods for analysis of soil nutrients (ed) Standard methods for analysis of soil nutrients, Yokendo, Tokyo, Japan, p.229-238, 1970 .

SHI, S.M. et al. Arbuscular mycorrhizal fungus species dependency governs better plant physiological characteristics and leaf quality of mulberry (Morus alba L.) seedlings. Frontiers in Microbiology, v.7, n.7, p.1030, 2016. Available from: <http:// dx.doi.org/10.3389/fmicb.2016.01030>. Accessed: Apr. 30, 2018. doi: $10.3389 /$ fmicb.2016.01030.

SIMARD, S.W.; DURALL, D.M. Mycorrhizal networks, a review of their extent, function, and importance. Canadian Journal of Botany, v.82, n.8, p.1140-1165, 2004. Available from: <http://dx.doi. org/10.1139/b04-116>. Accessed: Apr. 30, 2018. doi: 10.1139/b04-116.

SIMON, L. et al. Specific amplification of $18 \mathrm{~s}$ fungal ribosomal genes from vesicular-arbuscular endomycorrhizal fungi colonizing roots. Applied \& Environmental Microbiology, v.58, n. 1, p.291295, 1992. Available from: <http://dx.doi.org/10.1890/00129658(2001)082[2731:IOLFAF]2.0.CO;2>. Accessed: Apr. 30, 2018. doi: 10.1890/0012-9658(2001)082[2731:IOLFAF]2.0.CO;2.

TEIXEIRA-RIOS, T. et al. Seasonal differences in arbuscular mycorrhizal fungal communities in two woody species dominating semiarid caatinga forests. Folia Geobotanica, v. 53, n.2, p.191-200, 2018. Available from: <https://doi.org/10.1007/s12224-018-93147>. Accessed: Apr. 30, 2018. doi: 10.1007/s12224-018-9314-7.

VAN DER HEIJDEN, M.G.A. Arbuscular mycorrhizal fungi as support systems for seedling establishment in grassland. Ecology Letters, v.7, n.4, p.293-303, 2004. Available from: <http://dx.doi. org/10.1111/j.1461-0248.2004.00577.x>. Accessed: Apr. 30, 2018. doi: $10.1111 / \mathrm{j} .1461-0248.2004 .00577 . x$.

VAN DER HEIJDEN, M.G.A. et al. Mycorrhizal fungal diversity determines plant biodiversity, ecosystem variability and productivity. Nature, v.396, n.6706, p.1030, 2016. Available from: $<$ http://dx.doi.org/10.1038/23932>. Accessed: Apr. 30, 2018. doi: $10.1038 / 23932$

VAN DER HEIJDEN, M.G.A. et al. The mycorrhizal contribution to plant productivity, plant nutrition and soil structure in experimental grassland. New Phytologist, v.172, n.4, p.739-752, 2006. Available from: <http://dx.doi.org/10.1111/j.1469-8137.2006.01862.x>. Accessed: Apr. 30, 2018. doi: 10.1111/j.1469-8137.2006.01862.x.

VAN, DER, HEIJDEN, M.G.A. et al. The unseen majority, soil microbes as drivers of plant diversity and productivity in terrestrial ecosystems. Ecology Letters, v.11, n.3, p.296-310, 2008. Available from: $<$ http://dx.doi.org/10.1111/j.1461-0248.2007.01139.x >. Accessed: Apr. 30, 2018. doi: 10.1111/j.1461-0248.2007.01139.x.

VANDENKOORNHUYSE, P. et al. Co-existing grass species have distinctive arbuscular mycorrhizal communities. Molecular Ecology, v.12, n.11, p.3085-3095, 2003. Available from: <http:// dx.doi.org/10.1046/j.1365-294X.2003.01967.x>. Accessed: Apr. 30, 2018. doi: 10.1046/j.1365-294X.2003.01967.x.

WAGG, C. et al. Mycorrhizal fungal identity and diversity relaxes plant-plant competition. Ecology, v.92, n.6, p.1303-1013, 2011. 
Available from: <http://dx.doi.org/10.1890/10-1915.1>. Accessed: Apr. 30, 2018. doi: 10.1890/10-1915.1.

WALDER, F.; WIEMKEN, A. Mycorrhizal networks, common goods of plants shared under unequal terms of trade. Plant Physiology, v.159, n.2, p.789-797, 2012. Available from: <http:// dx.doi.org/10.1104/pp.112.195727>. Accessed: Apr. 30, 2018. doi: 10.1104/pp.112.195727.

WALKLEY, A. A critical examination of a rapid method for determining organic carbon in soils-effect of variations in digestion conditions and of inorganic soil constituents. Soil Science, v.63, n.63, p.251-264, 1947. Available from: <http://dx.doi. org/10.1097/00010694-194704000-00001>. Accessed: Apr. 30, 2018. doi: 10.1097/00010694-194704000-00001.

WANG, C. et al. Differences in arbuscular mycorrhizal fungal community composition in soils of three land use types in subtropical hilly area of Southern China. PLos One, v.6, n.10, p.e 0130983, 2015. Available from: <http://dx.doi.org/10.1371/ journal.pone.0130983>. Accessed: Apr. 30, 2018. doi: 10.1371/ journal.pone.0130983.

WANG, Q. et al. Spatio-temporal dynamics of arbuscular mycorrhizal fungi associated with glomalin-related soil protein and soil enzymes in different managed semiarid steppes. Mycorrhiza, v.24, n.7, p.525-538, 2014. Available from: <https:// doi.org/10.1007/s00572-014-0572-9>. Accessed: Apr. 30, 2018. doi: 10.1007/s00572-014-0572-9.
WANG, S.J. et al. Karst rocky desertification in southwestern China, geomorphology, landuse, impact and rehabilitation. Land Degradation \& Development, v.15, n.2, p.115-121, 2004. Available from: <http://dx.doi.org/10.1002/ldr.592>. Accessed: Apr. 30, 2018. doi: 10.1002/ldr.592.

XIANG, D. et al. Land use influences arbuscular mycorrhizal fungal communities in the farming-pastoral ecotone of northern China. New Phytologist, v.204, n.4, p.968-978, 2014. Available from: <http://dx.doi.org/10.1111/nph.12961>. Accessed: Apr. 30, 2018. doi: 10.1111/nph.12961.

ZHANG, Y. et al. Arbuscular mycorrhizal fungi associated with common pteridophytes in Dujiangyan, southwest China. Mycorrhiza, v.14, n.1, p.25-30, 2004. Available from: <http:/ dx.doi.org/10.1007/s00572-003-0272-3>. Accessed: Apr. 30, 2018. doi: 10.1007/s00572-003-0272-3.

ZHANG, Y. et al. Survey of arbuscular mycorrhizal fungi in deforested and natural forest land in the subtropical region of Dujiangyan, southwest China. Plant \& Soil, v.261, n.1-2, p.257-263, 2004. Available from: $<$ https://doi.org/10.1023/B:PLSO.0000035572.15098.f6>. Accessed: Apr. 30, 2018. doi: 10.1023/B:PLSO.0000035572.15098.f6.

ZHAO, D.; ZHAO, Z. Biodiversity of arbuscular mycorrhizal fungi in the hot-dry valley of the Jinsha River, southwest China. Mycorrhiza, v.37, n.1-2, p.118-128, 2007. Available from: $<$ https://doi.org/10.1016/j.apsoil.2007.06.003>. Accessed: Apr. 30, 2018. doi: 10.1016/j.apsoil.2007.06.003. 